\title{
Hocalı Soykırımının Tanınması İçin İslam İşbirliği Teşkilatının Aldığı Önlemler
}

\author{
The events of Organization Islamic Cooperation about the \\ recognition of Khojaly genocide
}

\section{Saida GULIYEVA*}

$\ddot{O} z$

$X X$. yüzyllın sonunda Ermenistan'ın Azerbaycan'a karşı işgalcilik politikasının en kanlı tarihi, Hocalı Soykirımı'dır. 26 Şubat 1992 yllinda Ermeni birlikleri ve paralı Rus askerleri Karabağ'da Hocalı şehrine saldırdılar. Bir gecede tarihi şehrin sivil halkı Türk ve Müslüman oldukları için soyktrıma maruz kaldl.

Azerbaycan Parlamentosu soykırımın yaşandı̆̆g andan itibaren gerçeklerin dünya kamuoyuna ulaştırllmasına çalışmaktadır. Hocalı Soykırımı ile ilgili dünya devletlerinin parlamentolarına ve uluslararası örgütlere başvurarak, Ermeni silahlı birliklerinin Hocalı'da soyktrım yaptıklarını ve bölgede katliamın önünü kesmeye çă̆ırmaktadır.

Azerbaycan hükümetinin uluslararası kurulușlara yaptı̆̆g bașvuruya, İslam İsbirliği Teşkilatı (IITT) tarafindan olumlu tepki verilmiştir. Bu politikanın reel sonuçlarında, İslam Konferansı Diyalog ve İşbirliği Gençlik Forumu (ICYF-DC) ve IITT Parlamenterler Birliğinin (IIIT PB) faaliyeti etkili olmuştur.

Araşttrma sonucunda, Hocall faciasının "soykirım" olarak kabul edilmesi, uluslararası hukuki değerin verilmesi yönünden belirli işler görülse de, kesin sonucun elde edilmediği anlaşılmıştır. $\ddot{U}_{c}$ ülke faciayı soykırım olarak tanıdı̆̆ını bildirmiștir.

\footnotetext{
* Junior research fellow, History department, Baku State University, seidequliyeva@gmail.com
} 
Alınmaya çalışılan tüm bu tedbirlerin amacl, bir daha bu gibi faciaların yaşanmaması için Hocalı Soykırımı'na dünya kamuoyu tarafindan hukuki-siyası ve manevi değerin verilmesini başarmaktır. Çă̆daş uluslararası hukukta bu gibi tutum, uluslararası kuruluşların ve büyük devletlerin tavrı ile belirlenmektedir. Hocalı Soykırımı'nın uluslararası ölçekte hukuki değerini kazanabilmesi için, Azerbaycan Cumhuriyeti Hükümeti ve IITT kurumları arasında işbirliğini zorunlu görmekteyiz.

Anahtar Kelimeler: Soykırım, Hocall, Azerbaycan, Uluslararası örgütler, İIT

\section{Abstract}

The mostbloody history of Armenia's invasion policy over Azerbaijan at the end of 20th century is Khojali genocide. On February 26, 1992 armenian military groups and hider russian troop invaded Khojaly, which was besiged at that time. Civil settlers of ancient city were incured to genocide only because of that they were turkish-muslim people.

Azerbaijan Parlament does its best to dispatch the realities of genocide to international world especially since the occurance of these events. The reaction to appeal of Azerbaijan administration to international organizations came from OIC. In this occasion, activites of ICYF-DC and RUIC cause to major results. At the result the resolutions of PUIC calls to recognize the massacre of Armenian military groups aganist civilians of Azerbaijan on February 26, 1992 and demands to incline guilties of this genocide to responsibility. This resolution is the first document, which recognized Khojaly tragedy by international organizatios.

Although there has been done some activities in the direction of recognition of Khojaly tragedy as "genocide" there has not been acquired any concrete result.

It is very essential to make cooperation between the administration of Azerbaijan Republic and organs of OIC in order to acquire political evaluation of genocide in international system.

Key Words: Genocide, Khojaly, Azerbaijan, International Organization, OIC

\section{Introduction}

The first international organization, which Azerbaijan entered after the declaration of state independence to is the Organization of Islamic Countries (OIC) ${ }^{1}$ Beginning from the entrence to OIC the independence of Azerbaijan was recognized by state-members of the organization along with the recognition of the inderpendence, there were created mutual realitions with the member states of OIC and opened the enbassies as well. Azerbaijan,

\footnotetext{
${ }^{1}$ According to the Resolution of 38th Islamic Conference (2011, June 28-30, Astana) of Ministers of Foregn Affairs, the name of the Organization of Islamic Conferance has been changed to the Organization of Islamic Coorparation sence 2011.
} 
which gained a chance to wtilize from information space and political support of Islamic world acoured a possiblity to exit from infotmation blocode, especially to warn the world population about the invasion policy of Armenia by the vehicle of theis organization.

First of all, Turkey, Iran, Pakistan, Saudia Arabia and other states of OIC began to shape diplomatic relations with Azerbaijan, as well as to defend the interests of Azerbaijan in international ceremonies. If we take into account the first years of the membership of Azerbaijan, then we can see that, the mitual relations were only in the level of humanitarian aid and moral support. And this was related with the war, occurred at the resuet of Armenis's invasion to Azerbaijan.

After Azerbaijan gained independence the Armenian aggressors in the Nagorno-Karabakh destructed hundreds of settlements and made thousands of people leave their homes. Hovewer, the Khojaly massacre was the most tragic of all.

The most bloody and hard history of the war in relared with Khojaly genocide. This genocide was the continuation of the genocide of Armenians, which they implemented the whole 20th century. There were killed 613 people (as well as, 106 women, 63 children, 70 old men), were ruined 8 families, 25 children loast both parents and 130 people lost one of the parents at the result of genocide.on February 26, 1275 civil people were captivated. After the conquer of this city and implementation of genocide over its people, Armenian military groups intersified the attachs to other settlement of Azerbaijan and the regions around Noroqno Karabakh were conqurred.

The organization made negotiations with Armenian administration during the years of 1991-1993, in which Armenia continued its military invasion to Azerbaijan lands. But as Armenis didn't change her expansive policy and didn't stop hostilities, the negotiations was stopped. OIC took into account the interests of Azerbaijan, which aftecupted to act together with OSCE and $\mathrm{UN}$, and to looked the for the ways of influence to Armenia. There was discussed expansionist policy on Armenia in Azerbaijan regions, there were accepted resolutions, which criticized agressive policy, crimes against civil polulation, distillation of people from their native lanols in Islam Sammits and in the conferences of OIC bodies. It is important to mention the 
participation of OIC and its member states in the adaption of UN resultions about Nagorno Karabakh as well ${ }^{2}$.

It is obvions that, the president of Azerbaijan Republic, H.A.Aliyev, who did his best to solve the problem of liberation of Azerbaijan lands from annexion in international level payed attention to wtilize from the opportunities of OIC. He stressed these issues beginning from the first official meeting with the official representatives of OIC and administrative chiefs of member countries of the organization, informed them about the results of Armenia aganist Azerbaijan and about the results of the war, inclined the organization to act much more concretely in these issues ${ }^{3}$.

\section{International legal-political attitude to Khojali Genocide}

The most bloody history of expansionist policy of Armenia aganist Azerbaijan was Khojaly genocide. Armenian military qroups together with hired russion army attacked to Khojali city on February $26,1992^{4}$. At that thus ancient city incured to the genocyde.

In the 10th year anniversary of the genocide the president of Azerbaijan Republic H.A.Aliyev nominated the racional plan in order to attain the ratification of this tragedy in legal-political an unternational level:

"The Khojali tragedy is a bloody page of the Armenian policy of ethnic cleansing and genocide against the Azerbaijani people which has been going on over two hundred years. This policy backed by some states was conducted during the tsarist Russia and Soviet period and resulted in mass deportation of the Azerbaijanis from their homes, and mass destruction after the collapse of the USSR. Two million Azerbaijanis suffered from the results of the Armenian policy of ethnic cleansing and genocide.

Today we have the duty to dispatch the reality about Khojaly genocide, commonly wildness of Armenians in Nagorno Krabakh to world countries, parliaments and sosieties, as well

\footnotetext{
${ }^{2}$ For wider information look: Quliyeva Saida, "H.A.Aliyev's role the formation of the position of Orqanization of Islamic Conference to the expansionist policy of Armenia aganist Azerbaijan (1991-2003). Diplomacy world. The journal of the Ministry of Foregn Affairs of Azerbaijan Republic. Baku, 27/2010, p.31-39.

${ }^{3}$ Haydar Aliyevand the East. In 6 volume. $5^{\text {th }}$ volume: OIC countries/ collecter. - Lecturer Q.Allahverdiyev, V.Sultanzadeh; editor M.Qurbanli. Baku: Chashioglu, 2005. - 357 pages; Quliyeva Saida, the mentioned work, p. 31-39.

${ }^{4}$ Boran Aziz, Khojaly genocide: causes, the methools, of implentation and results. Baku, Azərneshr, 2008, p.65-112.
} 
as to achieve to the ratification of this tragedy as true genocide. It is our poluty in civil and human front of the spirits of Khojaly martyrs. On the other side, to succeed to the legal-political evaluation of this tragedy in international world, to punish is ideologists, organizers and executers are the main terms in arder not to repeat such cruel acts against the mankind.

Now the Azerbaijani government and people must inform the world community about the massacre and achieve its recognition as a genocide. It is our debt for the martyrs of Khojali; at the same time, it is necessary to punish the organizers of that massacre.

The Azerbaijani government, citizens and diaspora abroad take a lot of measures for informing the world community about the massacre: books are being written, researches are being made, the massacre is being discussed in the parliaments of different countries and international organizations. Now it is important to pursue this course regularly and achieve the legal and political evluation of the tragedy internationally" 5 .

Khojaly genocide and the ussue of its recognition in international level are in the attention of the Parliament and the Ministry of Foreign Affairs of Azerbaijan Republic - from the first days.

The Parliament of Azerbaijan Republic appeals to word Parleaments and international organizations about Khojaly genocyde beginning from $1992^{6}$.

On March 13in 1992, the Supreme Soviet of the Republic of Azerbaijan appealed to the parliaments of the world to direct them to take into account the continuous attacks on Azerbaijani territories started a day before by Armenian Armed Forces and inform them about committed genocide in Khojaly by mentioned neighboring country. The Soviet challenged the international powers to prevent current exterminations and demand Armenia to stop trampling on international $\mathrm{law}^{7}$. This decision was the first official legal document adopted by the government of Azerbaijan which confirmed the Armenia's aggressive policy against Azerbaijan and assessed the Khojaly tragedy as genocide. According to the $10^{\text {th }}$ article, it was required by the Ministry of Foreign Affairs of Azerbaijan to accelerate and complete the

\footnotetext{
5 "Azerbaijan" paper, Fevruary 26, 2002.

${ }^{6}$ The Archive of the Parliament of Azerbaijan Republic.

${ }^{7}$ The Archive of the Parliament of Azerbaijan Republic. Fondation 2941. Survey 1, Work 19, s. $21-28$
} 
process of establishing diplomatic missions in foreign countries in order to improve international relations with them.

At the time mentioned, Azerbaijan, having no diplomatic missions abroad till that time, launched to establish and promote international relations with foreign countries and was accepted as a member of the UN. Therefore, since 1995in the applications adopted by the National Assembly of the Republic of Azerbaijan, aimed at getting the attention of international organizations and world powers, it was asked to condemn the current situation carried out as a result of the military aggression of Armenia, atrocities committed against the peaceful population, Armenian deportation of Azerbaijanis from their motherlands and changing the names of those territories ${ }^{8}$. In 1996, 2002, 2007 , such kind of applications were developed to acquire worthy results ${ }^{9}$.

These activities by the government of Azerbaijan, are very successful in the frame of the Organization of Islamic Countries.

\section{ICYF toward recognition of the Khojaly genocide.}

In 2006 at the initiative of Youth Forum for Cooperation ${ }^{10}(\mathrm{ICYF})^{11}$, the book named "Karabakh: facts and results" was established in Arabic as a series of "Humanitarian tragedies in the OIC countries". In the $33^{\text {rd }}$ Islamic Conference of Foreign Ministers the book was officially presented to delegations from 57 member states and was shared among media representatives.

On March 6, 2007in Jeddah, Islamic Conference of Cultural and Social Affairs as a high-level group of experts of the OIC discussed the draft decision proposed by ICYF which was about the Khojaly genocide. According to the resolution adopted in the conference, the member states unanimously recognized the Khojaly tragedy as the mass extermination committed by the Armenian armed forces against the peaceful Azerbaijani population $^{12}$.

General Coordinator of ICYF for Intellectual Dialogue, Leyla Aliyeva initiated "Karabakh Liberation-Justice for Khojaly" campaign on the anniversary day of occupation of Shusha (May 8, 2008). The campaign

\footnotetext{
${ }^{8}$ The Archive of the Parliament of Azerbaijan Republic. Fondation 2941. Survey 1, Work 313, s.38-40.

${ }^{9}$ The Parliament of Azerbaijan Republic // http://www.meclis.gov.az

${ }^{10}$ Islamic Conference Youth Forum for Dialogue and Cooperation (ICYF-DC) // http://www.icyf-dc.org/en

${ }^{11}$ It was created by the initiative of Azerbaijan in 2006/ Head-quarter of it is situated in İstambul.

12“"The paper of People”, March 8, 2007.
} 
meant to inform the world about the truth of the massacre and achieve legal, political and moral evaluation of the exterminations committed. In order to realize this mission, there was set up a website to extend the participants of the campaign throughout the year. Various news related to the genocide and actions, and applications addressed to different international organizations, parliaments and etc. were set on the site. The number showing the people who signed the application is 144448 for now ${ }^{13}$. The draft resolution about the Khojaly genocide, prepared at the initiative of ICYF was presented to several OIC conferences (the $4^{\text {th }}$ Islamic Conference of Ministers of Education, the $5^{\text {th }}$ Islamic Conference of Culture Ministers, the XXXIV and XXXV Islamic Summit of the Ministers of Foreign Affairs) ${ }^{14}$.

In the meeting of intergovernmental expert group (16-17 may 2008; Istanbul) ICYF and ISESCO together declare "Day of Commemoration" for the humanitarian tragedies committed against the OIC peoples and the date of Khojaly tragedy - 26 of February is included in the Joint Action Plan which is the appendix of "Istanbul Communique". There have been organized a number of important international events in order to realize the "Justice for Khojaly" campaign as part of the Plan of Action.

In the $4^{\text {th }}$ Islamic conference of the Ministers of Education (6-8october, 2008; Baku) it was decided to establish new academic courses in the OIC member states and include the true facts and materials about the Khojaly tragedy in textbooks of schools of higher education. "Justice for Khojaly" campaign is regarded as one of the priority actions of ISESCO in 2009-2012 years ${ }^{15}$.

In the conference named "Youth policy against Islamophobia" held in Baku in 2008, The Council of Europe and ISESCO decided to organize several international events in order to support the campaign and consequently, all the decisions were included in the Plan of Action.

According to the decision of the 39th Islamic Conference of the Foreign Ministers (15-17 November, 2012; Djibouti), the article recognizing the Khojaly tragedy as genocide was included in the draft resolution and it was

\footnotetext{
${ }^{13}$ Justice for Khojaly // http://justiceforkhojaly.org/site/mainpage.php

${ }^{14} 11$ th session of the Islamic Summit Conference // http://www.oic-

oci.org/is11/english/documents.asp; Thirty Fourth session of the Islamic Conference of

Foreign Ministers // http://www.oic-oci.org/34icfm/english/documents.htm; Resolutions of the 35th session of the council of Foreign Ministers// http://www.oic-

oci.org $/ 35 \mathrm{cfm} /$ english/documents.html

${ }^{15}$ Materials about Khojaly will be included to the text book of students of OIC countries // http://www.echo-az.com/archive/2008_10/1907/obshestvo03.shtml
} 
confirmed by all member states. The main content of the resolution is: "Cooperating with ISESCO and Parliamentary Union of the OIC Member States, ICYF tends to promote the program of "The humanitarian catastrophes against Muslim communities in the twentieth century". Aim of the "Justice for Khojaly" campaign is to inform the world about the truth of the mass extermination committed against Azerbaijani people by the Armenian Armed Forces in 1992 and challenge the member states to support the recognition of this massacre in international arena" ${ }^{16}$. It was an essential resolution toward truly presenting the known tragedy as genocide in international arena. This resolution was approved in 12th Islamic Conference held in Egypt in $2013^{17}$.

As you can see, the practical effect of this policy is more effective than the Islamic Conference Youth Forum.

Activities of the Parliamentary Union of the OIC member states toward recognition of Khojaly genocide.

The draft resolution prepared by the joint efforts of the National Assembly of the Republic of Azerbaijan and ICYF, was presented to the Parliamentary Union ${ }^{18}$ (OIC PU) ${ }^{19}$ and the materials developed by the National Assembly of the Republic of Azerbaijan, reflecting Armenia's aggressive policy and atrocities committed against the Azerbaijani people were distributed to the delegations of the member states. Consequently, 2

\footnotetext{
${ }^{16}$ Resolutions on Cultural and Social Affairs Adopted by the 39-th session of the Council of Foreign Ministers (Session of Solidarity for Sustainable Development) Djibouti, Republic of Djibouti. 15 - 17 november 2012 (01 - 03 muharram, 1434)// http://www.oicoci.org/english/conf/fm/39/CUL-RES-39-CFM-FINAL.pdf

17 12th session of the Islamic Summit Conference // http://www.oicoci.org/external_web/is/12/en/docs/final/is12_fc_rev2_en.pdf

${ }^{18} \mathrm{PUICC} / / \mathrm{http}: / /$ www.puic.org/english

${ }^{19}$ Parliamentary union of the OIC member states was established according to the decision adopted in the extraordinary Islamic Summit held in 1997. The delegation from Azerbaijan headed by M.Alasgarov, the chairman of the National Assembly, took part in the conference. Since the founding conference of OIC PU being held from 15 to 17 June in 1999 in Tehran, the organization took into action. The OIC PU is one of the largest inter-parliamentary union, gathering one fourth of the parliaments of the world together. As the main duties while developing multiple cooperation among legislative and advisory organs of the member states, creating legal base for the implementation of effective collaboration, promoting relations with international governmental and non-governmental organizations, OIC comply with the norms and principles of the international law. OIC PU supports the campaign "Justice for Khojaly". It should be added that in the $13^{\text {th }}$ plenary session o the IC PU (January 2011; Abu-Dhabi), TURK PA (Parliamentary Association) gained the observer status. (The National Assembly of Azerbaijan and Parliamentary union of the OIC member states. International cooperation. http://www.meclis.gov.az/?/az/content/54).
} 
articles relating to the situation in Nagorno-Karabakh were included in the final document in the $5^{\text {th }}$ conference of OIC PU (30-31 January, 2008, Cairo) 20

It should be emphasized that since the establishment of the OIC PU, issues about Armenia's aggressive policy have been always included in the agenda of the session. Resolutions adopted in the conferences of the PU strongly condemn "Armenia's aggression directed against sovereignty and territorial integrity of the Republic of Azerbaijan, considering it as gross violation of the principles of international law and the UN". The conference votes for "fully, unconditionally and immediate withdrawal of the Armenia's armed forces from all occupied territories of Azerbaijan" and challenges the member states "to strengthen solidarity with Azerbaijani people, increase cooperation with relevant regional and international organizations of the UN and with the attempts to use the potential of these organizations, try to gain support in recognition the sovereignty, territorial integrity of Azerbaijan as soon as possible " (April 2006, Istanbul; January 2010, Kampala ${ }^{21}$ ).

There was adopted the resolution (SSCPE/4-2010/DR/RES.26) about "the cooperation between ICYF and OIC PU" in the $6^{\text {th }}$ conference of the OIC PU (30-31 January, 2010, Kampala) ${ }^{22}$. Some provisions of the resolution fully support the campaign "Justice for Khojaly" and challenge the Parliaments of the member states to support the recognition of this massacre as "a crime against humanity" both in national and international spheres. The resolution was adopted in the conference gathering together the heads of the Parliaments of more than 10 countries, nearly 100 members of parliaments, delegates from several international organizations, as well as the representatives from the Parliamentary Union of Black Sea Economic Cooperation Organization, of which one of the members is Armenia ${ }^{23}$.

\footnotetext{
${ }^{20}$ Cairo Declaration Fifth Session of the Conference of the Parliamentary Union of the OIC Member States (PUIC) Cairo - Arab Republic of Egypt 30-31 January 2008 // $\mathrm{http}: / /$ www.puic.org/english/index.php?option=com_content\&task=view\&id=68\&Itemid=119; Respublika qəzeti. 02.02.2008. №024 (3159).

${ }^{21}$ The PUIC Conference Members have met at the following dates and places //

http://www.puic.org/english/index.php?option=com_content\&task=view\&id=92\&Itemid=246 ; Kampala Declaration Adopted by the Sixth Session of the PUIC Conference Kampala Republic of Uganda 30 - 31 January, 2010 //

http://www.puic.org/english/index.php?option=com_content\&task=view\&id=779\&Itemid=29 5

${ }^{22}$ Final Documents adopted by the Sixth Session of the PUIC Conference // http://www.puic.org/english/index.php?option=com_content\&task=blogcategory\&id=155\&It emid=295\&phpMyAdmin=YyatXOsTD1-TCBNJ3\%2CyOGZyfoC8

${ }^{23}$ The OIC PU has adopted the resolution supporting the "Justice for Khojaly" campaign. // http://www.lent.az/news.php?id=38171
} 
This resolution by the OIC is another document recognizing the massacre of Khojaly as "a crime against humanity".

The resolution was again approved in the $13^{\text {th }}$ session of the General Committee of the OIC (January 2011, Abu-Dhabi). According to the $3^{\text {rd }}$ article of the resolution, the parliaments of the member states of OIC PU recognize the mass extermination committed by Armenian armed forces against the peaceful Azerbaijani population in the town of Khojaly, as a crime against humanity. In the document, the member states are challenged to give the appropriate value to the massacre at the national level. The secretary-general of the ICYF, Ambassador Elshad Iskandarov noted that this document will qualitatively open the new stage in recognizing this genocide as part of Armenia's aggressive policy toward Azerbaijani people at the international sphere and making the criminals to take legal responsibility for the committed genocide ${ }^{24}$.

In the $8^{\text {th }}$ session of the OIC PU, there was adopted several amendments to the resolution named "Armenia's aggression against the Republic of Azerbaijan" ${ }^{25}$. In the article added at the initiative of the ICYF it was stated that "since 2012 (twenty-year anniversary of the tragedy), conference challenges the parliaments of the member states to recognize the mass extermination committed against the peaceful Azerbaijani population by the Armenian armed forces on February 26 in 1992 and requires to make the criminals take legal responsibility for perpetration the genocide" ${ }^{26}$. The conference has assigned an appropriate decision in the final report of the Secretariat, calling the parliaments of the member states to promote the implementation of the resolution, supporting the campaign "Justice for Khojaly" to be recognized at the international sphere. Commenting on the importance of the resolution the İCYF Secretary-General, Ambassador Elshad Iskandarov said that, first time this resolution gives the political and legal assessment to the Khojaly tragedy among other international documents and recognize this massacre as the genocide.

\footnotetext{
${ }^{24}$ Parliamentary Union of the Organization of the Islamic Conference passed of a special resolution international campaign in support "Justice for Khojaly". Fevruary 01, 012010 // http://az.apa.az/print.php?id=210548

${ }^{25}$ FINAL DOCUMENTS ADOPTED BY THE 7th SESION OF THE PUIC CONFERENCE PALEMBANG - REPUBLIC OF INDONESIA 24 - 31 JANUARY, 2012 // http://www.puic.org/english/index.php?option=com_content\&task=blogcategory\&id=181\&It emid $=331$

${ }^{26}$ The Khojaly tragedy was recognized as a "genocide" in the international sphere. http://az.apa.az/xeber_Xocali_faciesi_beynelxalq_seviyyede_249533.html
} 
It should be noted that the National Assembly of Azerbaijan and activities by the representatives of the campaign in the member states have significant influence on decision-making process in the IC $\mathrm{PU}^{27}$.

All these measures taken by the ICYF aimed at informing the world about the real truth of Khojaly tragedy, getting legal, moral and political assessment of the international community and as a result, having the fair treatment about the genocide. According to the modern international law, such attitude is determined by the position of the world powers and international organizations.

The events organized in OIC member states: in the direction of recognition of Khojaly genocide there are carried out definite also in OIC member states. In this respect, Ministry of Foreign Affairs of the Republic of Azerbaijan, Milli Majlis and The Islamic Conference Youth Forum's activities should be emphasized. The Ministry of Foreign Affairs agencies, parliaments, embassies and diaspora organizations, inform community together for the recognition of the tragedy through a variety of events.

These events are more organized in the Republic of Turkey. Public awareness about the genocide is different in Turkey and all around the world. Thus, as the nearest state in the region Turkey protected Azerbaijan`s interests from the first days of Armenia's aggressive policy. Information about severe social and economic tensions caused by the war and unbelievable crimes against civilians are emphasized by the Turkish government and influenced the decisions of OİC organizations ${ }^{28}$.

Along with this, Grand National Assembly of Turkey also holds discussions in order to give legislative evaluation to the most terrible history of the war. While recognition of Khojaly tragedy as genocide is being discussed in the Grand National Assembly of Turkey, Parliament approaches to this case because of different cautions. In 2005, members of the Parliament in the Grand National Assembly of Turkey has adopted document condemning the Khojaly genocide ${ }^{29}$.

In 2012, the events organized with cooperation of Turkish-Azerbaijani Inter-parliamentary Friendship Group, Azerbaijani embassy in Turkey and azerbaijanis living in Turkey according to the organization different from previous ones.

${ }^{27}$ The OIC PU has adopted the resolution supporting the "Justice for Khojaly" campaign. // http://www.lent.az/news.php?id=38171

${ }^{28}$ B.Aziz, p.95.

29 “Dirchalish”, Fevruary-March, 2005, № 84-85, p. 50-58. 
In Kuwait (2009), Turkmenistan (2010), Saudi Arabia (2010), Indonesia (2010, 2011), Morocco (2013), Qatar (2013) events on Khojaly genocide were held in different years.

Every year Islamic Youth Forum organizes different events within "Justice for Khojaly" campaign in OIC non-member states in America and Europe. These events are important or informing community about the genocide.

\section{Conclusion}

Researches show that there were made certain work on the recognizing Khojaly tragedy as a "massacre", on appraising its status according international law, but concrete results were not achieved.

Only Pakistan and Bosnia-Hersogovin Parliament among OIC memberstates has recognized the tragedy as a "massacre".

The structures of Azerbaijan Republic continue their work on forming justice attitude to Khojaly tragedy by the international organizations and countries. For ratification of the PIUC resolutions by the Parliaments of the OIC member-states the Parliament of Azerbaijan Republic, Ministry of Foreign Affairs of Azerbaijan Republic are implementing the policy of Azerbaijan government. The main support to this concern is made by ICYFDC.

After the ratification of the resolution "Cooperation between ICYF-DC and PIUC" there were created several opportunities to take regular initiatives on "Justice for Khojaly" campaign.

The only aim of implemented ceremonies is to gain the moral and political evaluation for Khojaly genocide bu international world, the formation of justice attitude to the tragedy. Such attitude in the contemporary law is determined with positions of powerful states and international organizations. Cooperation between Azerbaijan government and OIC structures is necessary on getting juridical status of Khojaly tragedy on the international level as a part of Armenian massacre policy against Azerbaijan. Existing facts give opportunity to this cooperation to be fruitful, but we should consider some nuances:

1) to call up (recommend) OIC member-states to ratify PIUC Resolution as a part of cooperation between the Parliaments of Azerbaijan Republic and certain countries.

2) to continue regular work of Azerbaijan Republic Parliament interparliamentary working groups. 
3) to recommend OIC member-states to carry out all Khojaly tragedy resolution responsibilities (anniversary day and etc.).

4) to determine ICYF Council members taking part in their countries Parliaments

5) to get involved those people to activities that are adequate for PIUC resolution and achieve the official cooperation of those countries.

As a result of our research we believe our offers will positively effect on the recognition of Khojaly massacre on the international level and on the punishment of guilty people. It's our human and civic duty before the souls of Khojaly martyrs. 


\section{RESOURCES AND RESEARCH}

“Dirchalish”, February-March, 2005, № 84-85, p. 50-58.

11th session of the Islamic Summit Conference // http://www.oicoci.org/is11/english/documents.asp

12th session of the Islamic Summit Conference // http://www.oicoci.org/external_web/is/12/en/docs/final/is12_fc_rev2_en.pdf

Boran Aziz, Khojaly genocide: causes, the methools, of implentation and results. Baku, Azərneshr, 2008. - 224 p.

Cairo Declaration Fifth Session of the Conference of the Parliamentary Union of the OIC Member States (PUIC) Cairo - Arab Republic of Egypt 30-31 January 2008 // http://www.puic.org

Final Documents adopted by the 7th sesion of the PUIC // http://www.puic.org

Final Documents adopted by the Sixth Session of the PUIC Conference // http://www.puic.org

Haydar Aliyevand the East. In 6 volume. $5^{\text {th }}$ volume: OIC countries/ collecter. Lecturer Q.Allahverdiyev, V.Sultanzadeh; editor M.Qurbanli. Baku; Chashioglu, 2005. - 357 pages

Islamic Conference Youth Forum for Dialogue and Cooperation (ICYF-DC) // http://www.icyf-dc.org/en

Justice for Khojaly // http://justiceforkhojaly.org/site/mainpage.php

Quliyeva Saida, “H.A.Aliyev's role the formation of the position of Orqanization of Islamic Conference to the expansionist policy of Armenia aganist Azerbaijan (191-2003". Diplomacy world. The journal of the Ministry of Foregn Affairs of Azerbaijan Republic. Baku, 27/2010, p.31-39; http://www.mfa.gov.az

Parliamentary Union of the Organization of the Islamic Conference // http://www.puic.org

Resolutions of the 35th session of the council of Foreign Ministers// http://www.oicoci.org $/ 35 \mathrm{cfm} /$ english/documents.html

Resolutions on Cultural and Social Affairs Adopted by the 39-th session of the Council of Foreign Ministers (Session of Solidarity for Sustainable Development) Djibouti, Republic of Djibouti. 15 - 17 november 2012 (01 - 03 muharram, 1434) // http://www.oic-oci.org/english/conf/fm/39/CUL-RES-39CFM-FINAL.pdf

The Archive of the Parliament of Azerbaijan Republic. Fondation 2941. Survey 1, Work 19. $-167 \mathrm{~s}$. 
The Archive of the Parliament of Azerbaijan Republic. Fondation 2941. Survey 1, Work 313. $-218 \mathrm{~s}$.

The National Assembly of Azerbaijan and Parliamentary union of the OIC member states. International cooperation. // http://www.meclis.gov.az/?/az/content/54

The OIC PU has adopted the resolution supporting the "Justice for Khojaly" campaign. // http://www.lent.az/news.php?id=38171

The Parliament of Azerbaijan Republic // http://www.meclis.gov.az

The PUIC Conference Members have met at the following dates and places // http://www.puic.org

Thirty Fourth session of the Islamic Conference of Foreign Ministers // http://www.oic-oci.org/34icfm/english/documents.htm

\section{Newspaper}

"Azerbaijan" paper, February 26, 2002.

"Republic" paper, February 02, 2008. №024 (3159

“The paper of People”, March 8, 2007

Materials about Khojaly will be included to the text book of students of OIC countries //http://www.echoaz.com/archive/2008_10/1907/obshestvo03. shtml

Parliamentary Union of the Organization of the Islamic Conference passed of a special resolution international campaign in support "Justice for Khojaly". February 01, $2010 / /$ http://az.apa.az/print.php?id=210548 
